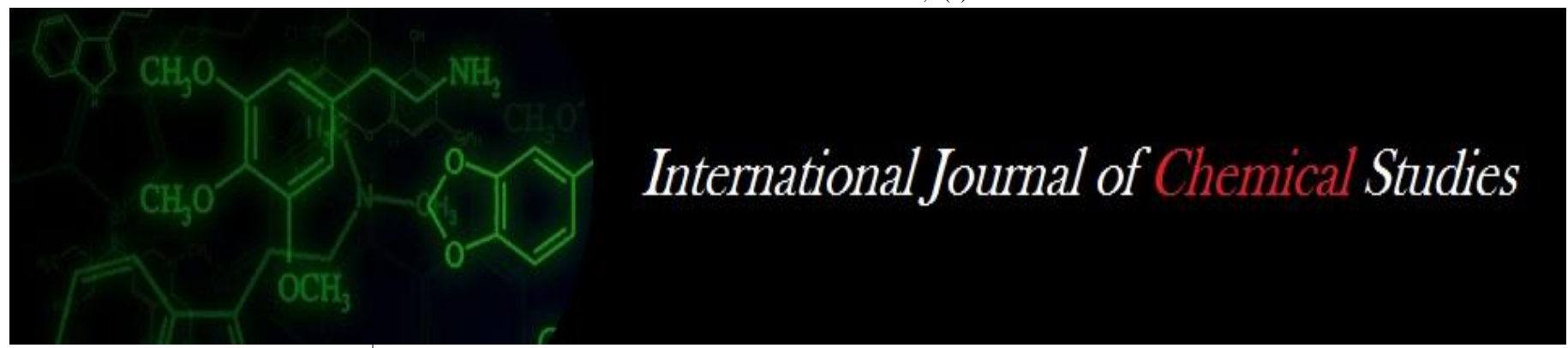

P-ISSN: 2349-8528

E-ISSN: 2321-4902

www.chemijournal.com

IJCS 2021; 9(1): 591-594

(C) 2021 IJCS

Received: 04-11-2020

Accepted: 12-12-2020

\section{Kanak Bhati}

Department of Genetics and

Plant Breeding, Navsari

Agricultural University, Navsari,

Gujarat, India

DA Chauhan

Pulses and Castor Research

Station, Navsari Agricultural

University, Navsari, Gujarat,

India

\section{Aditi D Patel}

Department of Genetics and

Plant Breeding, Navsari

Agricultural University, Navsari,

Gujarat, India

\section{Kajal C Rathod}

Department of Genetics and

Plant Breeding, Navsari

Agricultural University, Navsari,

Gujarat, India
Corresponding Author: Kanak Bhati

Department of Genetics and

Plant Breeding, Navsari

Agricultural University, Navsari,

Gujarat, India

\section{A study of heritability and genetic advance in pigeon pea. (Cajanus cajan (L.) Mill spp.)}

\author{
Kanak Bhati, DA Chauhan, Aditi D Patel and Kajal C Rathod
}

DOI: https://doi.org/10.22271/chemi.2021.v9.i1h.11294

\begin{abstract}
The present investigation was conducted at Pulses and Castor Research Station, Navsari Agricultural University, Navsari during Kharif 2017-20 with a view to study heterosis of four crosses (each having $\mathrm{P}_{1}$, $\mathrm{P}_{2}, \mathrm{~F}_{1}, \mathrm{~F}_{2}, \mathrm{BC}_{1}$ and $\mathrm{BC}_{2}$ generations) in a Compact Family Block Design with three replications. Out of four crosses studied, high heritability coupled with high to moderate genetic advance for trait grain yield per plant in cross I and IV; days to flowering in cross I and II; days to maturity in cross II and IV; reproductive phase duration in cross I, III and IV; Plant height in cross II, III and IV; primary branches per plant in cross IV and pods per plant in cross II and IV. Simple selection method would be fruitful for improvement of various characters because they are predominantly inherited by genetic effect. Involvement of environment effect is very less in inheritance of above-mentioned traits.
\end{abstract}

Keywords: Heritability, genetic advance, pigeon pea, $\mathrm{F}_{1}, \mathrm{~F}_{2}$, backcross generations

\section{Introduction}

Pigeon pea, a legume pulse crop, it is short lived woody perennial cultivated as annual crop in semi-arid tropical and subtropical regions of the world. Agronomically branching system in pigeon pea is classified as erect, semi-erect and spreading types. It originated in India and spread to Africa, were it formed secondary centre of biodiversity. Cajanus cajanifolious, is the only progenitor of pigeon pea. It has a seed strophiole which is only distinguishable morphological trait that differs it from cultivated pigeon pea. Pigeon pea is a diploid plant $(2 \mathrm{n}$ = 22) with a genome size of $852 \mathrm{Mbp}$. Protein content in commonly grown pigeon pea cultivars ranges between 17.9 to $24.3 \mathrm{~g}$ per $100 \mathrm{~g}$ for whole grain samples (Salunkhe et al., 1986). Regional name of pigeon pea in India are Toor in Hindi, Kandhi pappu in Telugu, thuvaran paruppu in Tamil, Togari bele in Kannada. Global perspective shows that pigeon pea could be considered a promising pulse crop that is cable of providing nutritional food security. After chickpea, pigeon pea is most important pulse crop which is widely grown in the country. Major pigeon pea growing states are Gujarat, Andhra Pradesh, Maharashtra, Uttar Pradesh, Madhya Pradesh, Karnataka and Bihar. India is leading in world production of pigeon pea, but still couldn't meet the country demand. Thus, it is a need to develop hybrids or varieties with high productivity. The major constraints that limit the production of pigeon pea are nonavailability of quality seeds of improved varieties in adequate quantity, poor crop management, biotic and abiotic stresses prevalent in the pigeon pea growing areas, besides socio-economic factors and narrow genetic base. For yield improvement, selection of superior parents possessing better heritability and genetic advance for yield contributing traits is an essential prerequisite. Heritability along with genetic advance is more useful than heritability alone in the prediction of resultant effect of selection.

\section{Materials and Methods}

The present investigation was carried out during Kharif 2017-20, at Pulses and Castor Research Station, Navsari Agricultural University, Navsari. In this experiment six generations viz., $\mathrm{P}_{1}, \mathrm{P}_{2}, \mathrm{~F}_{1}, \mathrm{~F}_{2}, \mathrm{BC}_{1}$ and $\mathrm{BC}_{2}$ of four crosses involving four diverse genotypes of pigeon pea were used to study the genetic analysis of quantitative traits. Randomly selected ten competitive plants from each of the $\mathrm{P}_{1}, \mathrm{P}_{2}, \mathrm{~F}_{1}$, forty plants from $\mathrm{F}_{2}$ and twenty plants from each of the $\mathrm{BC}_{1}$ and $\mathrm{BC}_{2}$ generations were utilized per replication and observations were recorded 
on single plant basis for the following characters except days to maturity where, observations were made on plot basis

\section{Estimation of heritability}

The narrow sense heritability, as suggested by Warner (1952) was calculated as follows:

$$
h_{(n)}^{2}(\%)=\frac{\sqrt{D}}{V F_{2}} X 100
$$

\section{Where \\ $\mathrm{h}^{2}{ }_{(\mathrm{n})}=$ Heritability in narrow sense \\ $\mathrm{D}=$ Additive genotypic variance \\ $\mathrm{VF}_{2}=$ Phenotypic variance}

Heritability percentage was categorized as demonstrated by Robinson et al. (1949) ${ }^{[19]}$.

$\begin{array}{ccc}\text { Sr. No. } & \text { Category } & \text { Percentage } \\ 1 & \text { Low } & 0-30 \% \\ 2 & \text { Moderate } & 30-60 \% \\ 3 & \text { High } & 60 \% \text { and above }\end{array}$

Estimation of expected genetic advance under selection

The expected genetic advance at five percent selection intensity was estimated by using the following formula.

$$
\text { E.G.A. }=k \cdot h_{(b)}^{2} \cdot \sigma_{p}
$$

Where,

$h_{(b)}^{2}=$ Heritability in broad sense

$\sigma_{p}=$ Phenotypic standard deviation

$k=$ Selection differential

$(\mathrm{k}=2.06$ at 5 percent selection pressure $)$

Expected genetic advance as per cent of mean was estimated by the following formula.

$$
\text { E. G. A. }(\text { per cent of mean })=\frac{\text { G.A. }}{\bar{X}} \times 100
$$

Where,

G. A. = Genetic advance

$\overline{\mathrm{X}}=$ Mean of the character under study

\section{Result and Discussion}

Heritability estimates along with genetic advance are important selection parameters and normally more helpful in predicting the gain under selection than heritability estimates alone. However, heritability estimates are influenced by the type of genetic material, sample size, method of sampling, type of experiment, method of calculation and effect of linkage. Genetic advance which refers to the improvement in the mean genotypic value of selected individuals over the parental population is influenced by the genetic variability, heritability, and selection intensity (Sharma, 2003) ${ }^{[15]}$.

The results obtained on these aspects for different characters studied in four crosses of pigeon pea viz., cross I (GNP-401 x NPMK-14-01), cross II (GNP-401 x GNP-1B), cross III (GNP-401 x NPMK-15-02) and cross IV (GNP-401 x NPDK15-12) here after referred to as cross I, cross II, cross III and cross IV respectively are presented and discussed in the following paragraphs.

For trait grain yield per plant (Table 2), out of four crosses high heritability $(101 \%)$ coupled with high genetic advance
(28.04\%) was found in cross IV. High heritability $(52.66 \%)$ coupled with moderate genetic advance $(13.08 \%)$ was found in cross I. Similar results were reported by Patel et al. (2011) [10], Yerimani et al. (2013) [18], Saroj et al (2014) [13], Niranjana Kumara et al. (2014) [8], Bhanu et al. (2016) [5], Mallesh et al. (2017) ${ }^{[7]}$ and Bal et al. (2017) ${ }^{[3]}$ for grain yield per plant. This estimate offers most suitable condition for selection. It also indicates the presence of additive gene effect in the trait and further suggests reliable crop improvement through selection of this trait

For trait days to flowering (table 1), high heritability coupled with moderate genetic advance was found in cross I $(132.46 \%, 10.16 \%)$ and cross II $(123.19 \%, 13.00 \%)$. Thus, days to first flowering trait could be improved via individual plant selection method.

Cross II $(155.96 \%, 52.05 \%)$ and cross IV (151.57\%, 20.04\%) showed highly heritable and had high genetic advance value for trait days to maturity (table 1), cross II $(160.02 \%, 54.49 \%)$ and cross IV $(159.96 \%, 22.06 \%)$ reproductive phase duration (table 1) and pods per plant), cross II $(138 \% \%, 63.80 \%)$ and cross IV $(111 \%, 189 \%)$ (Table 1). Similar results were obtained by Udensi et al. (2011) ${ }^{[17]}$ Patel et al. (2011) ${ }^{[10],}$ Yerimani et al. (2013)) ${ }^{[18]}$, Saroj et al. (2014) ${ }^{[13]}$, Niranjana Kumara et al. (2014) [8], Ram et al. (2016) ${ }^{[12]}$, Bal et al. (2017) ${ }^{[3]}$, and Pal et al. (2018) ${ }^{[9]}$. Thus, to improve traits with high heritability and high genetic advance, simple selection method would be most suitable.

High heritability couple with high genetic advance was found in cross II $(123 \%, 84.68 \%)$ and cross IV $(99.46 \%, 41.15 \%)$, for trait plant height (table 1). Similar results were obtained by Patel et al. (2011) ${ }^{[10]}$, Sharma et al. (2012) ${ }^{[14]}$ and Ram et al. (2016) ${ }^{[12]}$ for plant height. Simple selection would be fruitful in improvement of trait plant height.

For trait primary branches per plant (table 1), showed high heritability with moderate genetic advance value in cross IV $(125.40 \%, 12.69 \%)$ (Table 1). Similar results were obtained by Niranjana Kumara et al. (2014) ${ }^{[8]}$, Mallesh et al (2017) ${ }^{[7]}$, Pal et al. (2018) ${ }^{[9]}$ for days to flowering; Sharma et al. (2012) [14]. Individual plant selection method would be fruitful for improvement of this trait.

High heritability coupled with low genetic advance value was found in cross II $(54.71 \%, 0.33 \%)$, III $(50.50 \%, 7.67 \%)$ and IV $(125.40 \%, 12.69 \%)$ for primary branches per plant (table $1)$; cross I $(129.04 \%, 1.13 \%)$ and cross III $(140.40 \%, 4.99 \%)$ for pod length (table 2); cross I $(101.10 \%, 1.05 \%)$, cross II $(49.22 \%, 0.25 \%)$, cross III $(49.87 \%, 0.86 \%)$ and cross IV $(155.20 \%, 1.66 \%)$ for seeds per pod(table 2); cross I $(147.64 \%, 2.36 \%)$, cross $\mathrm{II}(139.76 \%, 1.52 \%)$, cross III $(146.72 \%, 1.21 \%)$ and cross $\operatorname{IV}(154.25 \%, 1.74 \%)$ for 100 seed weight (table 2); cross II $(41.12 \%, 5.99 \%)$, cross III $(92.57 \%, 7.83 \%)$ and cross $\operatorname{IV}(65.54 \%, 2.29 \%)$ for leaf area (table 2); cross I(116.93\%), cross II(122.72\%, 5.17\%) and cross III $(166.24 \%, 9.79 \%)$ for harvest index (table 2); cross $\mathrm{I}(30.58 \%, 1.09 \%)$, cross $\mathrm{II}(42.01 \%, 0.07 \%)$ and cross IV $(99.21 \%, 0.78 \%)$ for trait protein content (table 1). Similar results were obtained by Birhan et al. (2013) ${ }^{[6]}$ for primary branches per plant; Bhanu et al. (2016) ${ }^{[5]}$ and Pushpavalli et al (2018) ${ }^{[11]}$ for secondary branches per plant; Udensi et al. (2011) ${ }^{[17]}$, Bhadru. (2011) ${ }^{[4]}$ for pod length; Yerimani et al. (2013) ${ }^{[18]}$ and Ram et al. (2016) ${ }^{[12]}$ seeds per pod; Udensi et al. (2011) [17], Yerimani et al. (2013) ${ }^{[18]}$ and Ram et al. (2016) ${ }^{[12]}$ for pod length; Pushpavalli et al. (2018) ${ }^{[11]}$ for 100 seed weight. Direct selection should be avoided for improvement of above-mentioned trait because influence of environment is more in expression of above-mentioned trait in mentioned crosses. 
Table 1: Estimates of heritability and genetic advance in four crosses of pigeon pea for days to first flowering, days to maturity, reproductive phase duration, plant height, primary branches per plant, secondary branches per plant and pods per plant

\begin{tabular}{|c|c|c|}
\hline Character and cross & Narrow sense heritability (\%) & Genetic advance \% mean \\
\hline \multicolumn{3}{|c|}{ Days to first flowering } \\
\hline GNP-401 X NPMK-14-01 & 132.46 & 10.16 \\
\hline GNP-401 X GNP-1B & 123.19 & 13.00 \\
\hline GNP-401 X NPMK-15-02 & 185.31 & 4.99 \\
\hline GNP-401 X NPDK-15-12 & 90.29 & 7.45 \\
\hline \multicolumn{3}{|c|}{ Days to maturity } \\
\hline GNP-401 X NPMK-14-01 & 8.10 & 9.38 \\
\hline GNP-401 X GNP-1B & 155.96 & 52.05 \\
\hline GNP-401 X NPMK-15-02 & 32.79 & 8.39 \\
\hline GNP-401 X NPDK-15-12 & 151.57 & 20.04 \\
\hline \multicolumn{3}{|c|}{ Reproductive phase duration (days) } \\
\hline GNP-401 X NPMK-14-01 & 78.51 & 11.16 \\
\hline GNP-401 X GNP-1B & 160.02 & 54.49 \\
\hline GNP-401 X NPMK-15-02 & 23.18 & 8.48 \\
\hline GNP-401 X NPDK-15-12 & 159.96 & 22.06 \\
\hline \multicolumn{3}{|c|}{ Plant height (cm) } \\
\hline GNP-401 X NPMK-14-01 & 66.29 & 3.71 \\
\hline GNP-401 X GNP-1B & 123.00 & 84.68 \\
\hline GNP-401 X NPMK-15-02 & 59.68 & 20.82 \\
\hline GNP-401 X NPDK-15-12 & 99.46 & 41.15 \\
\hline \multicolumn{3}{|c|}{ Primary branches per plant } \\
\hline GNP-401 X NPMK-14-01 & 79.74 & 2.45 \\
\hline GNP-401 X GNP-1B & 54.71 & 0.33 \\
\hline GNP-401 X NPMK-15-02 & 50.50 & 7.67 \\
\hline GNP-401 X NPDK-15-12 & 125.40 & 12.69 \\
\hline \multicolumn{3}{|c|}{ Secondary branches per plant } \\
\hline GNP-401 X NPMK-14-01 & 16.58 & 11.24 \\
\hline GNP-401 X GNP-1B & 147.49 & 3.16 \\
\hline GNP-401 X NPMK-15-02 & 79.32 & 6.05 \\
\hline GNP-401 X NPDK-15-12 & 54.22 & 1.55 \\
\hline \multicolumn{3}{|c|}{ Pods per plant } \\
\hline GNP-401 X NPMK-14-01 & 14.15 & 56.41 \\
\hline GNP-401 X GNP-1B & 138.92 & 63.80 \\
\hline GNP-401 X NPMK-15-02 & 32.39 & 13.44 \\
\hline GNP-401 X NPDK-15-12 & 111.04 & 189 \\
\hline
\end{tabular}

Table 2: Estimates of heritability and genetic advance in four crosses of pigeon pea for pod length, seeds per pod, 100 seed weight, grain yield per plant, leaf area, harvest index and protein content

\begin{tabular}{|c|c|c|}
\hline Character and cross & Narrow sense heritability (\%) & Genetic advance \% mean \\
\hline \multicolumn{3}{|c|}{ Pod length (cm) } \\
\hline GNP-401 X NPMK-14-01 & 129.04 & 1.13 \\
\hline GNP-401 X GNP-1B & 57.21 & 0.85 \\
\hline GNP-401 X NPMK-15-02 & 140.40 & 2.99 \\
\hline GNP-401 X NPDK-15-12 & 28.67 & 2.13 \\
\hline \multicolumn{3}{|c|}{ Seeds per pod } \\
\hline GNP-401 X NPMK-14-01 & 101.10 & 1.05 \\
\hline GNP-401 X GNP-1B & 49.22 & 0.25 \\
\hline GNP-401 X NPMK-15-02 & 49.87 & 0.86 \\
\hline GNP-401 X NPDK-15-12 & 155.20 & 1.66 \\
\hline \multicolumn{3}{|c|}{ 100 seed weight (g) } \\
\hline GNP-401 X NPMK-14-01 & 147.64 & 02.36 \\
\hline GNP-401 X GNP-1B & 139.76 & 01.52 \\
\hline GNP-401 X NPMK-15-02 & 146.72 & 01.21 \\
\hline GNP-401 X NPDK-15-12 & 154.25 & 01.74 \\
\hline \multicolumn{2}{|c|}{ Grain yield per plant (g) } \\
\hline GNP-401 X NPMK-14-01 & 52.66 & 13.08 \\
\hline GNP-401 X GNP-1B & 16.84 & 09.94 \\
\hline GNP-401 X NPMK-15-02 & 24.19 & 18.77 \\
\hline GNP-401 X NPDK-15-12 & 101.19 & 28.04 \\
\hline \multicolumn{2}{|c|}{ Leaf area (cm $)$} \\
\hline GNP-401 X NPMK-14-01 & 02.94 & 04.20 \\
\hline GNP-401 X GNP-1B & 41.12 & 05.99 \\
\hline GNP-401 X NPMK-15-02 & 92.57 & 07.83 \\
\hline GNP-401 X NPDK-15-12 & 65.54 & 02.29 \\
\hline \multicolumn{2}{|c|}{$\sim 59$} \\
\hline
\end{tabular}




\begin{tabular}{|c|c|c|}
\hline \multicolumn{2}{|c|}{ Harvest index (\%) } \\
\hline GNP-401 X NPMK-14-01 & 116.93 & 04.52 \\
\hline GNP-401 X GNP-1B & 122.72 & 05.17 \\
\hline GNP-401 X NPMK-15-02 & 166.24 & 09.79 \\
\hline GNP-401 X NPDK-15-12 & 33.49 & 02.65 \\
\hline \multicolumn{2}{|c|}{ Protein content (\%) } \\
\hline GNP-401 X NPMK-14-01 & 30.58 & 01.09 \\
\hline GNP-401 X GNP-1B & 42.01 & 00.7 \\
\hline GNP-401 X NPMK-15-02 & 27.58 & 00.77 \\
\hline GNP-401 X NPDK-15-12 & 99.21 & 02.74 \\
**-significant at 1\% level of significance *-significant at 5\% level of significance
\end{tabular}

\section{Conclusion}

High heritability coupled with high genetic advance was found in cross II and IV for trait days to maturity; cross II and IV reproductive phase duration; cross II and IV in plant height; cross I and IV for pods per plant; cross IV for grain yield per plant. High heritability coupled with moderate genetic advance was found in cross I and II for days to first flowering; cross I for reproductive phase duration; cross IV for primary branches per plant; cross II for leaf area. Thus, it could be concluded that maximum traits in many crosses showed high heritability along high, moderate and low genetic advance. Thus, to improve the overall population for all the traits biparental mating followed by pedigree method or cyclic breeding methods could be used for improvement of this trait. Traits with low genetic advance, selection for such traits could be delayed to latter generation.

\section{References}

1. Anonymous. ICRISAT, Annual Report, Patancheru, Andhra Pradesh, India, 2011, 52. ISSN-1017-9933

2. Alza JO, Martinez JMF. Genetic analysis of yield and related traits in sunflower (Helianthus annus L.) in dryland and irrigated environments. Euphytica, 1997;95:243-251.

3. Bal CP, Bhave SG, Thaware BL, Desai SS, Mahadik SG, Nair KP. Variability studies in early genotypes of pigeon pea (Cajanus cajan (L.) Millsp.). Global Journal of Bioscience and Biotechnology 2017;6(3):520-522.

4. Bhadru D. Genetic studies in pigeon pea (Cajanus cajan (L.) Mill sp). Electronic Journal of Plant Breeding 2011;2(1):132-134.

5. Bhanu NA, Singh MN, Rathore AS, Hemantaranjan A, Saroj SK. Study of heterosis and inbreeding depression for yield attributing characters in Pigeon pea. The Journal of Plant Science Research 2016;32(2):143-148.

6. Birhan T, Zeleke H, Ayana A, Tilahun A, Chemeda A. Genetic variability, heritability and genetic advance in early maturing pigeon pea (Cajanus cajan L.) genotypes. World Journal of Agricultural Sciences 2013;1(7):241247.

7. Mallesh P, Nanda HC, Durgaraju C, Sameer Kumar CV, Mohan N, Galian JK. Variability, Heritability and Genetic Advance for Quantitative Traits in Pigeon pea (Cajanus cajan (L.) Mill sp.). International Journal Pure Applied Biosciences 2017;5(5):25-28.

8. Niranjana Kumara B, Dharmaraj PS, Vijaya BW. Genetic diversity and variability studies of advanced breeding lines of Pigeon pea (Cajanus cajana. L). International Journal of Advances in Pharmacy, Biology and Chemistry 2014;3(2):404-409.

9. Pal D, Verma SK, Panwar RK, Arora A, Amit KG. Correlation and Path Analysis Studies in Advance Lines of Pigeon pea [Cajanus cajan (L.) Millspaugh] under
Different Environments. International Journal of Current Microbiology and Applied Sciences 2018;7(4):378-389.

10. Patel JB, Acharya S, Joshi VC, Vaghela KO. Genetic Variability and Character Association Study in IndoAfrican Derivatives of Pigeon pea. Annals of Arid Zone 2011;50(2):167-169.

11. Pushpavalli SN, Yamini KN, Anuradha R, Kumar G, Sudha R, Sudhakar C, et al. Genetic variability and correlation in pigeon pea genotypes. Electronic Journal of Plant Breeding 2018;9(1) 343-349.

12. Ram K, Kanak S, Tushar SM, Geeta B. A study on genetic variability, correlation and path analysis in pigeon pea [Cajanus cajan L. Millspaugh]. International Journal of Agriculture Sciences 2016;8(51):2287-2289.

13. Saroj SK, Singh MN, Singh T. Combining Ability, Heterosis and Inbreeding Depression Analysis for Using CMS Lines in Long Duration Pigeon pea. International Journal of Research Studies in Biosciences 2014;2(10):715.

14. Sharma R, Gangwar RK, Yadav V. A Study on Genetic Variability and Correlation in Pigeon Pea [Cajanus cajan (L) Millsp.]. International Journal of Science and Research 2012;3(9):826-828.

15. Sharma SN. Genetics of spike length in durum wheat. Euphytica 2003;130:155-161.

16. Singh NP. Webinar (Revisiting strategy for Seelf sufficiency in Pulses: Introspection) organized by Indian Institute of Pulses, Kanpur, 2020. (https://www.youtube.com/watch?v=qUzCKn2tOoI).

17. Udensi O, Edu EA, Umana UJ, Ekpeme EJ. Estimation of genetic variability in locally grown pulses (Cajanus cajan (L.) Millspp and Vigna unguiculata (L) walp): A panaceae for superior genotypes. Pakistan journal of Biological Sciences 2011;14(6):404-407.

18. Yerimani AS, Mehetre S, Kharde MN. Genetic Variability for Yield and Yield Component Traits in Advanced $\mathrm{F}_{3}$ and $\mathrm{F}_{4}$ Generations of Pigeon pea [Cajanus cajan (L.)]. Molecular Plant Breeding 2013;4(16):136140.

19. Robinson HF, Comstock RE, Harvey VH. Estimation of heritability and degree of dominance in corn. Agronomy J 1949;41:353-359. 